\title{
GCSE Accounting
}

A Teachers' Guide

\author{
D. E. Turner \\ and \\ P. H. Turner
}

$\mathrm{M}$ 
(C) D. E. Turner and P. H. Turner 1991

All rights reserved. No reproduction, copy or transmission of this publication may be made without permission.

No paragraph of this publication may be reproduced, copied or transmitted save with written permission or in accordance with the provisions of the Copyright, Design and Patents Act 1988, or under the terms of any licence permitting limited copying issued by the Copyright Licensing Agency, 33-4 Alfred Place, London WC1 7DP.

Any person who does any unauthorised act in relation to this publication may be liable to criminal prosecution and civil claims for damages.

First edition 1991

Published by

Macmillan Education Ltd

Houndmills, Basingstoke, Hampshire RG21 2XS

and London

Companies and representatives

throughout the world

ISBN 978-0-333-54664-2

ISBN 978-1-349-12195-3 (eBook)

DOI 10.1007/978-1-349-12195-3

Every attempt has been made to ensure the accuracy of the answers. Nevertheless, errors can unfortunately still 'creep through' and the authors apologise for any inconvenience or concern which may arise should there be any errors in the text or in this Guide. They would be very grateful for a note of any which are found, and for any comments which lecturers may care to make on the text generally. 


\section{CONTENTS}

1. Overview of the Book 1

1. Aims and Objectives 1

2. Structure of the Text 2

3. Activities and Assignments 2

4. MCQs in the Classroom 2

5. The Appendices 3

6. A Suggested Teaching Approach 3

7. The National Curriculum 4

8. Accountancy Teaching in Overseas Countries 5

$\begin{array}{ll}\text { 2. Commentary on the Units and Answer Guide } & 7\end{array}$

$\begin{array}{cl}\text { Part One } & 7 \\ \text { Unit } 1 & 7\end{array}$

Part Two

Unit 2

Unit 3

Unit 4

Unit 5

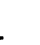
(

(

(3)

4

Part Three

Unit 6

Unit 7

Unit 8

Unit 9

Part Four

Unit $10 \quad 16$

Unit $11 \quad 17$

Unit $12 \quad 17$

$\begin{array}{ll}\text { Unit } 13 & 18\end{array}$

Part Five $\quad 20$

Unit $14 \quad 20$

Unit $15 \quad 21$

Unit $16 \quad 22$

Unit $17 \quad 23$

$\begin{array}{ll}\text { Part Six } & 24\end{array}$

Unit $18 \quad 24$

Unit $19 \quad 25$

Unit $20 \quad 25$

$\begin{array}{ll}\text { Unit } 21 & 27\end{array}$

Part Seven $\quad 28$

Unit $22 \quad 28$

Unit $23 \quad 28$

Unit $24 \quad 30$ 
Unit 25

Part Eight

34

Unit 27

34

Unit 28

35

Unit 29

36

Unit 30

37

3. Answers to the Multiple-choice Questions 